University of Texas at El Paso

\title{
DigitalCommons@UTEP
}

Rhetoric and Composition $\mathrm{PhD}$ papers

Department of English

$1-1-2005$

\section{Seeking a Rhetoric of the Rhetoric of Dis/abilities}

Scott Lunsford

The University of Texas at El Paso, sslunsford@utep.edu

Follow this and additional works at: http://digitalcommons.utep.edu/rhet_comp

Comments:

(C) Lawrence Erlbaum Associates, 2005. This is the authors' version of the work. It is posted here by permission of Lawrence Erlbaum Associates, Inc. for your personal use. Not for redistribution. The definitive version was published in: Rhetoric Review. 2005, Vol. 24, No. 3, Pages 330-333.

http://www.leaonline.com/doi/abs/10.1207/s15327981rr2403_6

\section{Recommended Citation}

Lunsford, Scott, "Seeking a Rhetoric of the Rhetoric of Dis/abilities" (2005). Rhetoric and Composition PhD papers. Paper 1.

http://digitalcommons.utep.edu/rhet_comp/1

This Article is brought to you for free and open access by the Department of English at DigitalCommons@UTEP. It has been accepted for inclusion in Rhetoric and Composition PhD papers by an authorized administrator of DigitalCommons@UTEP. For more information, please contact lweber@utep.edu. 
Seeking a Rhetoric of the Rhetoric of Dis/abilities

There exists a disability of the rhetoric of disabilities.

There are collective labels: the disabled, the deaf, the blind. Insults: rip, retard. Euphemisms:

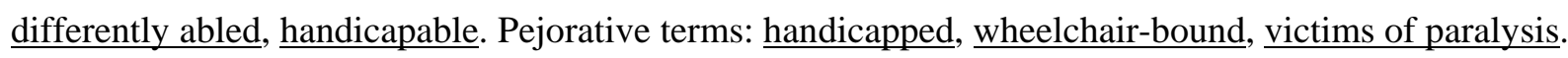
Plato's terms: deformed, lunatic. There are those deemed "appropriate”: people with disabilities, people who use wheelchairs. And then there are no words for those who do not talk about disabilities. There is only silence.

As an advocate for including dis/ability studies alongside the critical and traditional triumvirate of race, class, and gender, I was excited to see the disability symposium in a recent issue of Rhetoric Review (22.2). I use the form dis/abilities to emphasize the importance of its inclusion as an issue of difference which we approach as critically as we do race, class, and gender: Just as we cannot discuss race without arguing how "whiteness"—at least in this country—performs hegemonic control over other racial identities, we cannot ignore how “ability” realizes its constituent disability. But how do we go about discussing dis/ability? How do we move out of this silence and unawareness which strengthen stigma about various forms of disability?

I imagine a metadiscussion to realize a more complicated discourse of disabilities, a discourse which must confront its own disability. First, we must understand the hegemony which makes dis/ability invisible through silence. To put this notion into a context of race, some members of "white” society remain color-blind and resist talking about race, rendering race invisible. As such, some members of an ableistic society sometimes choose to be silent about disability; thus, disability remains invisible. Ability, too, can be invisible. Those of us who are "able-bodied" might not see it because we are it. Plus, we often do not see that our ability constructs disability. Second, once we've made dis/ability visible, we can then expand our awareness through language by becoming sensitive to various terminologies assigned to various disabilities. Last, we must always question the language we use so that we do not slip back into hegemonic unawareness, where we simply take for granted yet another term (handicapped or person with 


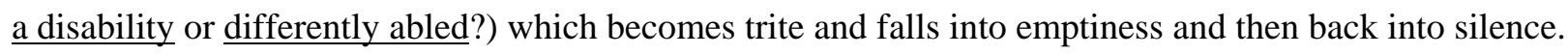
My interest here, then, is to provide a metadiscussion of the discourse of dis/abilities, examining some of the symposium authors' use of discourse in their articles and related texts: the rhetoric of the rhetoric of dis/abilities, if you will.

The first step in this process can be exemplified in Lend Me Your Ear: Rhetorical Constructions of Deafness, by Brenda Jo Brueggemann, who with Georgina Kleege wrote the symposium article “Gently Down the Stream: Reflections on Mainstreaming.” In her book, Brueggemann uses the forms

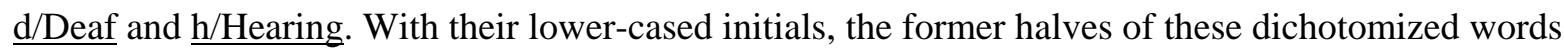
signify the audiological aspects of deafness and hearing; the latter halves denote cultural significance. Yet while those who consider themselves belonging to a Deaf culture, those of us who consider ourselves Hearing might not necessarily assign the initial-capped $\underline{\mathrm{H}}$ designation; some of us just might not realize we are part of a Hearing culture.

But should we hearing folks consider ourselves part of a Hearing culture? Wouldn’t it further marginalize those who are deaf and hard-of-hearing by making it obvious that we want our own designation in our ableistic community? Maybe. We who hear provide the normative basis for those who do not hear and who are hard of hearing. Once we realize that idea, we become part of the Hearing culture, and then we are able to see the hegemonic control over Deaf culture. Awareness of hegemony established, we can then further this awareness into the realization of how words and their concepts maintain control over "other” halves of conceptually dichotomized cultures.

As I move to the use of words- the second step to this envisioned process—-I will invoke Brueggemann again. In Lend Me Your Ear, she asserts that she does not want to focus on words alone: "Rather than to turn to the text, as Aristotle might prefer, and analyze the terms on its page, I favor a more process-centered and person-dominated over a product-centered and strictly linguistic approach” (27). But I must consider that, as rhetoric is interested in studying words and the realities they create, we do indeed pay attention to words sometimes on their own merit. Doing so, we bring sensitivity to the various uses of words and realize their rhetorical value. 
For example, Cynthia Lewiecki-Wilson, in her symposium article, "Representing Disability Rhetorically,” cites collective labels such as the severely mentally retarded and mentally ill; the disabled (157); and schizophrenics (163), yet in the introduction to Embodied Rhetorics, she and coeditor James Wilson use person-first terms such as disabled people with mental illness and cognitive impairments (10). The first group of words, the collective labels, has by some advocates been deemed "negative"; these terms not only ignore individual identity by labeling people collectively, but also maintain that the person is the disability itself. The person-first terms within the second group, a single phrase, are considered "affirmative" or "appropriate"; the person comes before the disability, not seen as the disability or grouped under a label. I may seem to be criticizing what looks like an inconsistency in term use, but instead I am trying to complicate the issue so that I myself can become more sensitive to these uses. We have a multitude of words to choose from, and we must become sensitive to their kairotic natures and the implications for using them rhetorically.

For instance, newspapers may write the disabled in a headline because the appropriate phrase people with disabilities doesn't fit. Does this usage further marginalize those in wheelchairs who want to be known as people with disabilities and not the disabled? Perhaps. But what about those who call themselves "handicapped”? This term seems inappropriate to advocates for disability issues. Who gets to choose — the advocate, the person with the disability, or the community of people with disabilities as a whole? Further, is it appropriate for two people in wheelchairs to call each other "crip” and inappropriate for an "outsider" to give either one of them the same pleasantry? Sure. Shared language strengthens the identity of a discourse community. On the other hand, what authority does anyone have over owning language that others can't use?

So, yes, discussing words, and ultimately asking why we valorize some words over others, is important. How else do we perform metadiscussions without these words, words appropriate or not? When we stop interrogating the rhetoricity of rhetoric we stop theorizing about our own discipline. I think it's safe to say that we might never find the answers to Why?, but it doesn't mean we shouldn't ask the questions about our own rhetorics. When we stop complicating any rhetoric, its discourse may become 
fixed, second-nature, and taken for granted. We stop thinking about that discourse, and, eventually, it becomes trite and slips into silence and then invisibility. We cannot stop questioning what becomes commonplace: "It must be that way because it’s always been that way.” And, thus, we cannot stop questioning authority.

Science, for example, in its authoritative "absolutism” and “objectivity,” should not escape criticism of labels used about people with disabilities. Should we not question scientific terms which are set firm because of their very "scientificity”? James Wilson takes on this question in his symposium article, “Evolving Metaphors of Disease in Postgenomic Science: Stigmatizing Disability.” He examines terms used in eugenics, terms which can be figuratively attached to attributes shared by people with disabilities. The eugenics movement, Wilson says, attempts in part to “eliminate so-called 'defectives'” such as “deadbeat,” “oft-shifty,” “renegade,” and “immigrant” DNA sequences (199). Genes termed as mutants, lesions, and errant “are cast as misfits that subvert the social collective” (198). Thus, these metaphors "are profoundly disturbing to many members of the disability community” (199). If these terms are set by science, what is the likelihood for change? Does science prevail while rhetoric continues only to ask questions?

Probably. But the fact that we are even asking questions about terms and tropes leads to awareness. When we become aware that science is not always linguistically appropriate, that there might just be a Hearing culture, that terms not yet created will someday be so and people will have their disagreements with these new terms as well—when we become conscious of all of these and more, we will not return to hegemonic unawareness where dis/abilities are invisible. Deconstructing questions must always be asked, for if we become satisfied with our answers, we run the risk of slipping back into our own comfortable silence.

Scott Lunsford University of Texas at El Paso 


\section{Works Cited}

Brueggemann, Brenda Jo. Lend Me Your Ear: Rhetorical Constructions of Deafness. Washington, D.C.: Gallaudet U P, 1999.

Symposium: Representing Disability Rhetorically. Ed. Theresa Enos. Rhetoric Review. 22.2 (2003): 154202.

Wilson, James C., and Cynthia Lewiecki-Wilson, eds. Embodied Rhetorics: Disability in Language and Culture. Carbondale: Southern Illinois U P, 2001. 